\title{
Short-term Toxicity studies with Triphenyltin Compounds in Rats and Guinea-pigs
}

\author{
H. G. Verschuuren, R. Kroes, H. H. Vink and G. J. van Esch \\ National Institute of Public Health, Utrecht, Netherlands
}

(Received 22 December 1965)

\begin{abstract}
Short-term toxicity studies have been carried out in rats and guinea-pigs fed diets containing triphenyltin acetate (TPTA), triphenyltin hydroxide (TPTH) or triethyltin hydroxide (TETH) for 90 days at levels ranging from 0 to $50 \mathrm{ppm}$.

The lowest dietary levels found to retard growth in rats and guinea-pigs respectively are as follows: 5 and $10 \mathrm{ppm}$ for TETH; 25 and $5 \mathrm{ppm}$ for TPTA; 50 and $20 \mathrm{ppm}$ for TPTH. An increase in mortality was found in the following groups: rats on $10 \mathrm{ppm}$ or more of TETH; guinea-pigs on 20 and 50 ppm TPTA and on $50 \mathrm{ppm}$ TPTH. In rats and guinea-pigs given TETH, paralysis and pronation of the hindlegs developed. These toxic signs were not found in the TPTA- and TPTH-treated animals. This observation was correlated with the finding that only the TETH-treated animals developed interstitial oedema of the central nervous system. The water content of the brain and spinal cord was increased in rats and guinea-pigs at respective minimum levels of 5 and $10 \mathrm{ppm}$ of TETH and in guinea-pigs on $20 \mathrm{ppm}$ TPTA. In female rats given 50 ppm TPTA or TPTH the water content of the spinal cord was only"increased.

The changes in organ weights which could be related to the administration of the organotin compounds were confined to an increase of brain weight in rats and guinea-pigs given TETH, and in guinea-pigs given 5 ppm or more of TPTA and a decrease of thymus and/or spleen weights in rats and guinea-pigs receiving TETH. Guinea-pigs given 5-20 ppm TPTA or 2.5-20 ppm TPTH displayed lymphopenia accompanied in a number of animals by histological changes in the lymphopoietic system, viz. atrophy of the white pulp of the spleen was found. This possibly induced a decrease of general resistance, so that a mycotic infection developed in the animals.

Hitherto, damage to the central nervous system was considered to be the most sensitive criterion for assessing the toxicity of organotin compounds, but the present work shows that the effect on lymphopoiesis is a more sensitive index of toxic action for triphenyltin compounds.
\end{abstract}

\section{INTRODUCTION}

Triphenyltin acetate (fentin acetate, TPTA) and triphenyltin hydroxide (fentin hydroxide, TPTH) are used as agricultural fungicides to combat Phytophtora infestans in potatoesf Septoria apii in celery and Cercospora beticola in sugar-beets. The short-term toxicity os TPTH in rats has now been compared with that of TPTA. A similar comparative study was also carried out in guinea-pigs because preliminary experiments indicated that this specie, would be more susceptible.

Magee, Stoner \& Barnes (1957) found that 10 to $20 \mathrm{ppm}$ of triethyltin hydroxide (TETH) given for 2-7 wk exerted a toxic action on the central nervous system of the rat which was described as interstitial oedema and characterized by an increase of brain weight, an increase in the water content of the brain and spinal cord and by histopathological changes in the white matter of these organs. This microscopic picture presented a distension of the spinal cord and cerebral fibre tracts separating the nerve sheaths by the inter-communicating spaces which contain an aqueous fluid. The brain and spinal cord lesions resulted in disturbances of nervous function, with paresis leading to death. 
In the present studies, special attention was paid in both species to the induction of interstitial oedema by TPTH and TPTA. For the purpose of comparison experiments with TETH were also included.

\section{EXPERIMENTAL}

Materials. TPTH and TPTA were .obtained from Philips-Duphar N.V., Amsterdam, Netherlands. TPTH, a white organic smelling powder, had the following characteristics: dry weight $99.99 \%$; content (acidimetric) $97 \cdot 1 \%$; ionogenic chlorine $0 \cdot 16 \%$; insoluble matter in benzene $1.5 \%$; uncorrected m.p. $118-119^{\circ} \mathrm{C}$.

TPTA, a white acetate smelling powder, had a content (acidimetric) of $94.5 \%$; a content (alkaline) of $96 \cdot 4 \%$; uncorrected m.p. $124-124 \cdot 5^{\circ} \mathrm{C}$.

TETH is a typical smelling white powder, with uncorrected m.p. $50^{\circ} \mathrm{C}$. This compound was obtained from Prof. Dr. van der Kerk.

Animals and diet. Six 90-day toxicity studies were carried out in rats and guinea-pigs, over a period of $1.5 \mathrm{yr}$. In each experiment 4-6 groups of 20 or more animals, equally divided by sex, were used. Rats and guinea-pigs were litter mates divided equally between experimental and control groups. Wistar rats were obtained from our own established colony at an age of $4 \mathrm{wk}$. The albino guinea-pigs used were derived from a stock that had been reared over $8 \mathrm{yr}$ in the animal supply department of our Institute, and were $3 \mathrm{wk}$ old when the test began.

The animals were housed in wire cages in groups of 2 or 3 according to sex. The initial body weights of the rats and guinea-pigs were $40-60 \mathrm{~g}$ and $130-200 \mathrm{~g}$ respectively. Rats were supplied with a powdered standard diet consisting of two thirds of whole wheat flour, one third of whole milk powder with addition of $0.5 \%$ sodium chloride and $0.5 \%$ calcium carbonate.

Guinea-pigs received three times a week a standard diet in unpelleted form in which the test compounds were mixed. Food and drinking water were given ad lib.

Dosage. The dietary levels employed were $0,5,10$ and $20 \mathrm{ppm}$ TETH, 0, 5, 10, 25 and $50 \mathrm{ppm}$ TPTA and 0, 5, 10, 25 and $50 \mathrm{ppm}$ TPTH in rats, and $0,5,10$ and $20 \mathrm{ppm}$ TETH, $0,5,10,20$ and $50 \mathrm{ppm}$ TPTA and $0,2 \cdot 5,5,10,20$ and $50 \mathrm{ppm}$ TPTH in guinea-pigs.

\section{Conduct of experiment}

Rats and guinea-pigs were weighed weekly and the average daily food consumption of the rats in each cage was recorded during wk 1, 2, 5, 9 and 12. The general appearance and behaviour were also noted. Haematological studies were carried out terminally and involved haemoglobin estimation, erythrocyte and leucocyte counts and blood picture determination. The total number of lymphocytes were calculated from the data obtained. The liver, kidneys, heart, spleen, thymus, adrenals, thyroid, pituitary gland, uterus, ovaries, testes, prostate, pancreas and brain were removed and weighed.

Sections from these organs (5-7 $\mu$ thick) and also from spinal cord, skeletal muscle, gastro-intestinal tract and urinary bladder, were fixed in $10 \%$ formalin and stained with haemalum and eosin for microscopic examination. Transverse sections were made of the spinal cord at more than one level and of the brain through the cerebellum and cerebrum. Sections of the brain and spinal cord were also stained with Lillie's variant of the WeilWeigert method for myelin (Lillie, 1954).

The water content of the brain and spinal cord was determined terminally usually by the 
method of drying to constant weight at $100^{\circ} \mathrm{C}$, but in the group of guinea-pigs given TPTA, estimations were made by iodometric titration employing the method of Karl-Fischer (Eberius, 1958).

The method of Wilcoxon (1945) was applied to test the statistical differences between test and control values. The results of these studies are summarized and only the statisticallysignificant deviations are mentioned.

\section{Animal behaviour and appearance}

\section{RESULTS}

In rats and guinea-pigs after 3-8 wk and 1-3 wk respectively, paralyses followed by or combined with pronation of the hindlegs set in at levels of 10 and $20 \mathrm{ppm}$ of TETH. In 4 male rats on $10 \mathrm{ppm}$, recovery occurred during wk 7-11. In one female rat on $5 \mathrm{ppm}$ TETH signs of paralysis were seen after 4 wk, but 2 wk later the animal recovered. In two rats given $10 \mathrm{ppm}$ TETH slight alopecia at the back was found.

The triphenyltin-treated animals did not exhibit any of these toxic signs.

\section{Growth and food consumption}

Male and female rats on 5 ppm TETH and on $25 \mathrm{ppm}$ TPTA and females on $50 \mathrm{ppm}$ TPTH showed a slight decrease in food consumption. At levels of $10 \mathrm{ppm}$ TETH and higher, $50 \mathrm{ppm}$ TPTA and $50 \mathrm{ppm}$ TPTH the corresponding reductions in dietary intake were more pronounced.

The food consumption could not be determined in guinea-pigs since the water partially evaporated from the food and since the animals spilled their food. The growth rates of rats and guinea-pigs given TETH, TPTA or TPTH are shown in Figs. 1 and 2. For the sake of clarity those growth curves which did not deviate from the corresponding control curves are not included. Table 1 gives the maximum no-effect and the minimum effect levels in respect of growth.

Table 1. Dose levels of TETH, TPTA and TPTH with and without effect on growth in rats and guinea-pigs

\begin{tabular}{|c|c|c|c|c|c|}
\hline \multirow[b]{2}{*}{ Substance } & \multirow[b]{2}{*}{ Species } & \multicolumn{2}{|c|}{$\begin{array}{l}\text { Highest dose level without } \\
\text { effect on growth (ppm) }\end{array}$} & \multicolumn{2}{|c|}{$\begin{array}{l}\text { Lowest dose level with } \\
\text { effect on growth (ppm) }\end{array}$} \\
\hline & & Females & Males & Females & Males \\
\hline \multirow[t]{2}{*}{ TETH } & Rat & - & - & 5 & 5 \\
\hline & Guinea-pig & 5 & 10 & 10 & 20 \\
\hline \multirow[t]{2}{*}{ TPTA } & Rat & 50 & 10 & - & 25 \\
\hline & Guinea-pig & - & 5 & 5 & 10 \\
\hline \multirow[t]{2}{*}{ TPTH } & Rat & 50 & 25 & - & 50 \\
\hline & Guinea-pig & 10 & 10 & 20 & 20 \\
\hline
\end{tabular}

The three organotin compounds all produced growth retardation in both species in the following order of magnitude: for the rat TETH $>$ TPTA $>$ TPTH and for the guinea-pig TPTA > TETH > TPTH. The guinea-pig was more sensitive than the rat in respect of the two triphenyltin compounds. There was also a tendency for male rats to be more sensitive than females.

In general, the growth retardation in rats ran parallel with the decrease in food consumption. In guinea-pigs, food consumption was not measured and thus no correlation was possible. 

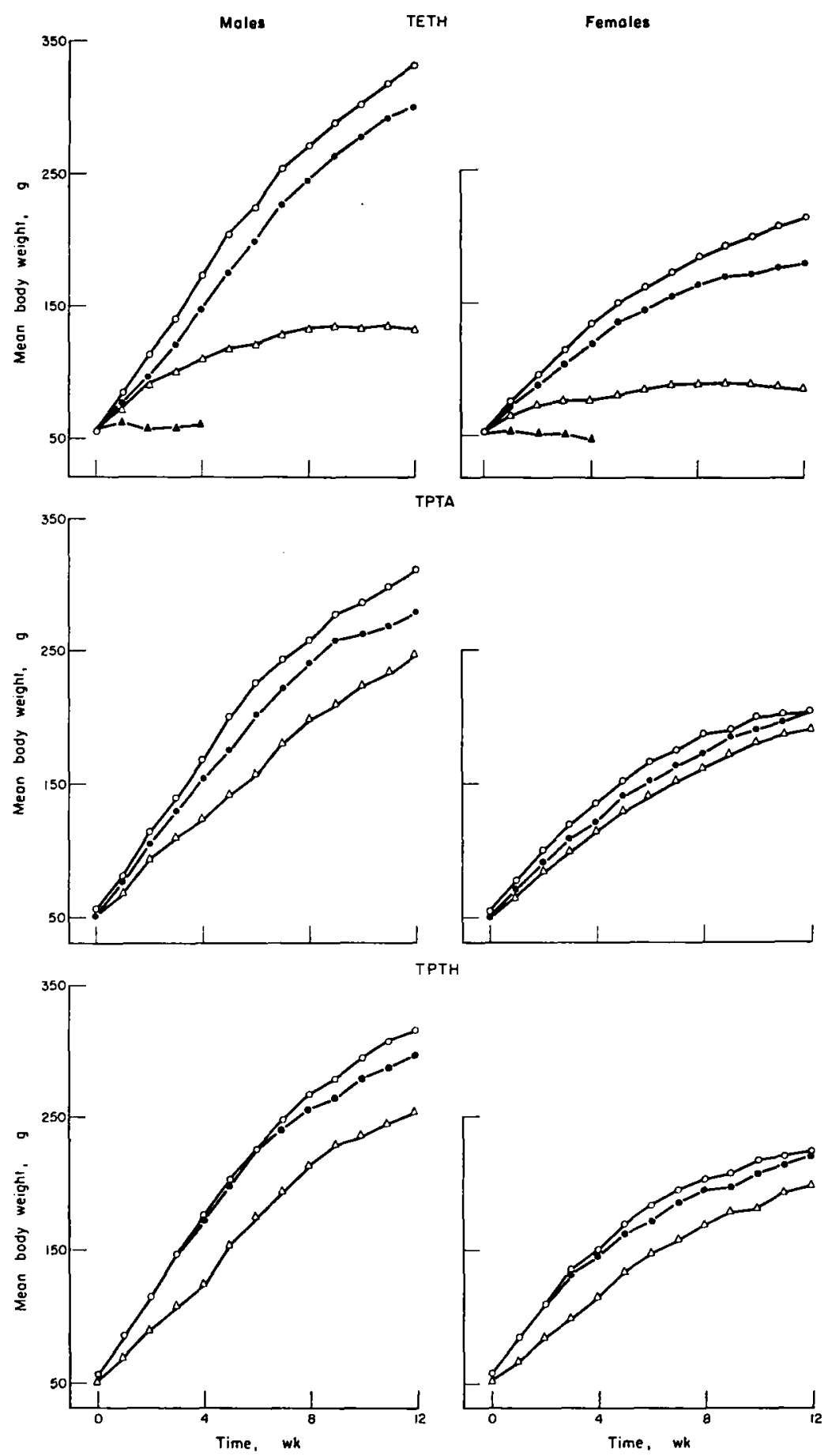

Fig. 1. Effects of TETH, TPTA and TPTH on growth of male and female rats. Dietary levels used are as follows: TETH $-0(0), 5(0), 10(\Delta)$ and $20(\Delta)$ ppm; TPTA $-0(0), 25(0)$ and $50(\Delta)$ ppm; TPTH-0 $(0), 25(O)$ and $50(\Delta)$ ppm. 

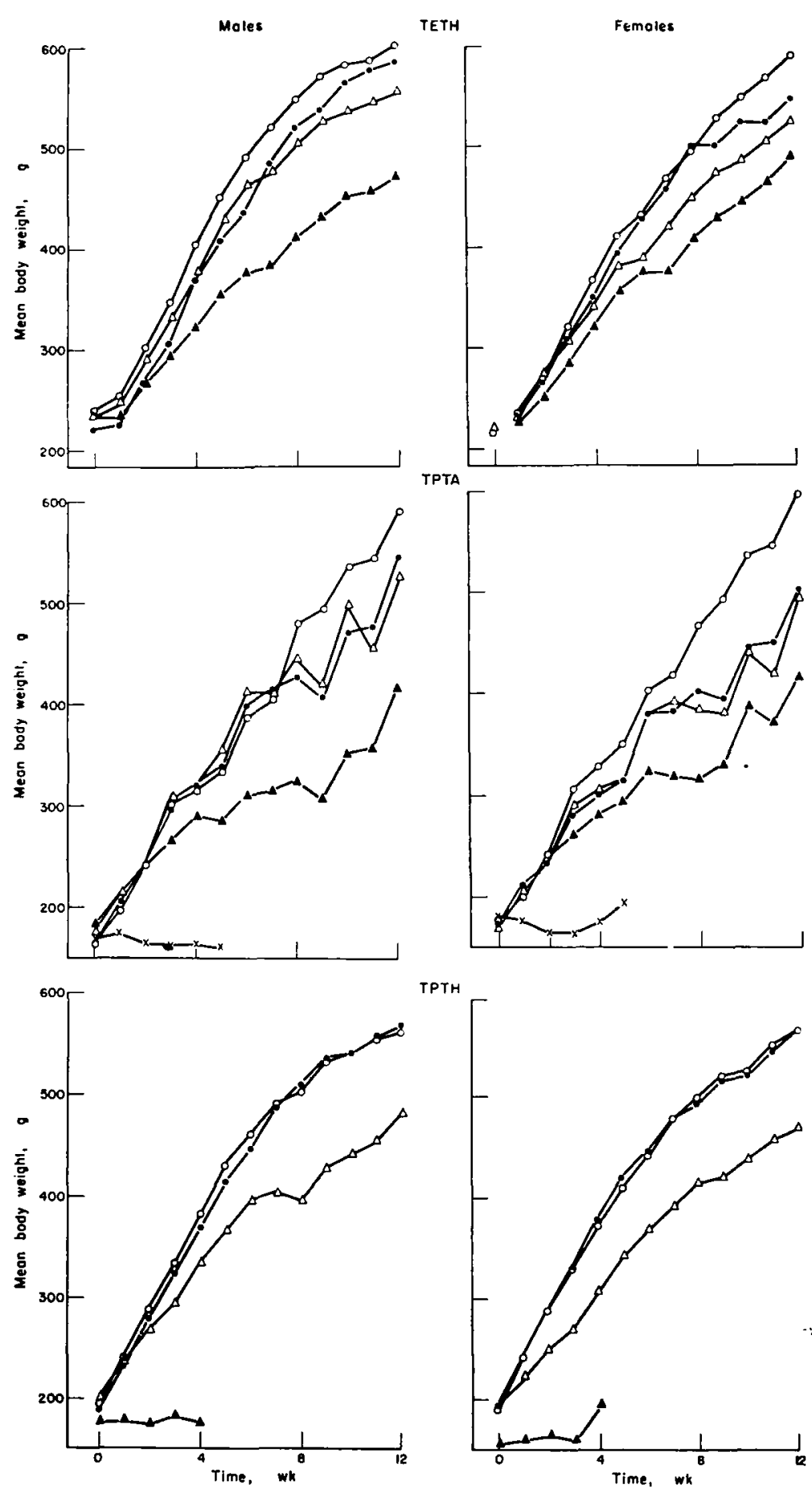

Fio. 2. Effects of TETH, TPTA and TPTH on growth of male and female guinea-pigs. Dietary levels used are as follows: TETH $-0(0), 5(0), 10(\Delta)$ and $20(\Delta)$ ppm; TPTA $-0(0), 5(0), 10(\Delta), 20(\Lambda)$ and $50(x)$ ppm; TPTH $-0(0), 10(0), 20(\Delta)$ and $50(\Delta)$ ppm. 


\section{Haematology}

Rats on $10 \mathrm{ppm}$ TETH showed an increased percentage of neutrophiles. Details of the number of leucocytes and lymphocytes are given in Table 2. The percentage of lymphocytes was decreased in the males but this was not significant. At the 5 and $10 \mathrm{ppm}$ levels a decrease in the number of erythrocytes in male rats was found. Guinea-pigs on 10 and 20 ppm showed a non-significant decrease. in the number of lymphocytes.

Table 2. Leucocyte and lymphocyte counts in rats and guinea-pigs given TETH, TPTA or TPTH at dietary levels of 0-50 ppm for $12 \mathrm{wk}$

\begin{tabular}{|c|c|c|c|c|c|c|c|c|c|}
\hline \multirow[b]{2}{*}{ Compound } & \multirow[b]{2}{*}{ Species } & \multirow[b]{2}{*}{ Sex } & \multicolumn{7}{|c|}{ Leucocyte and lymphocyte counts at a level of } \\
\hline & & & 0 & $2 \cdot 5$ & 5 & 10 & 20 & 25 & 50 \\
\hline \multicolumn{10}{|c|}{ Leucocytes $\left(10^{3} / \mathrm{mm}^{3}\right)$} \\
\hline TETH & Rat & Female & 9 & & 11 & 11 & & & \\
\hline TPTA & & & 10 & & $9 \cdot 7$ & $9 \cdot 1$ & & $9 \cdot 1$ & $8 \cdot 8$ \\
\hline TPTH & & & 11 & & $8^{*}$ & 8* & & $7 \ddagger$ & $8 \cdot 3 \S$ \\
\hline TETH & & Male & 10 & & 11 & 10 & & & \\
\hline TPTA & & & $12 \cdot 3$ & & $10 \cdot 5$ & $9 \cdot 3 \dagger$ & & $9 \cdot 6^{*}$ & 9.4* \\
\hline TPTH & & & 11 & & 9* & 9 & & 10 & $9 \cdot 4 * \S$ \\
\hline TETH & Guinea-pig & Female & 8 & & 9 & 7 & 9 & & \\
\hline TPTA & & & 6.8 & & $4.6 \pm$ & $4 \cdot 4 \ddagger$ & $3.9 \pm$ & & \\
\hline TPTH & & & $8 \cdot 7$ & $6.6^{*}$ & $6 \cdot 5^{\circ}$ & $5.9+$ & $4.9+$ & & \\
\hline TETH & & Male & 10 & & 9 & 8 & 8 & & \\
\hline TPTA & & & $6 \cdot 4$ & & $5 \cdot 4$ & $4 \cdot 7^{*}$ & $3 \cdot 1 t$ & & \\
\hline TPTH & & & $8 \cdot 1$ & $7 \cdot 4$ & $7 \cdot 6$ & $6 \cdot 8$ & $6 \cdot 1^{*}$ & & \\
\hline \multicolumn{10}{|c|}{ Lymphocytes $\left(\mathbf{1 0}^{3} / \mathrm{mm}^{3}\right)$} \\
\hline TETH & Rat & Female & $8 \cdot 1$ & & $9 \cdot 3$ & 8.8 & & & \\
\hline TPTA & & & $9 \cdot 0$ & & $7 \cdot 8$ & $7 \cdot 7$ & & $7 \cdot 7$ & $7 \cdot 7$ \\
\hline TPTH & & & 8.7 & & $6.9^{*}$ & $6.8^{*}$ & & $5.9+$ & $7 \cdot 1 \S$ \\
\hline TETH & & Male & $9 \cdot 0$ & & $9 \cdot 7$ & 8.5 & & & \\
\hline TPTA & & & $11 \cdot 1$ & & $9 \cdot 3$ & $8 \cdot 3$ & & $8 \cdot 5$ & $8 \cdot 3$ \\
\hline TPTH & & & $9 \cdot 4$ & & $8 \cdot 4$ & 7.8 & & 8.0 & $8.2 \S$ \\
\hline TETH & Guinea-pig & Female & 6.9 & & 7.8 & 5.6 & $6 \cdot 2$ & & \\
\hline TPTA & & & $5 \cdot 5$ & & $4 \cdot 0+$ & $3.7 \dagger$ & $3.4 \dagger$ & & \\
\hline TPTH & & & $7 \cdot 5$ & $5 \cdot 7^{*}$ & $5 \cdot 3^{*}$ & $4.2 \dagger$ & $3.8 \dagger$ & & \\
\hline TETH & & Male & 6.9 & & 6.9 & $5 \cdot 1$ & $4 \cdot 7^{\circ}$ & & \\
\hline TPTA & & & 4.9 & & $4 \cdot 4$ & $3.6^{\circ}$ & $2.5 t$ & & \\
\hline TPTH & & & $6 \cdot 6$ & $5 \cdot 9$ & $6 \cdot 5$ & $5 \cdot 1^{*}$ & $4.5 t$ & & \\
\hline
\end{tabular}

-Significantly different from controls: $0.05 \geqslant P>0.01$.

+Significantly different from controls: $0.01 \geqslant P>0.001$.

ISignificantly different from controls: $P \leqslant 0.001$.

$\S$ This group must be compared with the control group of TPTA.

Decreases were seen in the haemoglobin content of male rats on $50 \mathrm{ppm}$ TPTA and in the number of leucocytes in male rats given 10,25 or $50 \mathrm{ppm}$ TPTA. In female guinea-pigs on 5,10 and $20 \mathrm{ppm}$ TPTA and males on 10 and $20 \mathrm{ppm}$ a lymphopenia was found.

In female, but not in male rats on 5,10 and $25 \mathrm{ppm}$ TPTH a decrease in number of lymphocytes (lymphopenia) was found. In female guinea-pigs on 2.5, 5, 10 and $20 \mathrm{ppm}$ and in males on 10 and $20 \mathrm{ppm}$ TPTH the haemoglobin content was decreased. The number of erythrocytes remained unchanged. In the same groups, except the male group on $10 \mathrm{ppm}$, the number of leucocytes was decreased. A lymphopenia was found in female guinea-pigs on $2 \cdot 5,5,10$ and $20 \mathrm{ppm}$ and in males on 10 and $20 \mathrm{ppm}$. 


\section{Organ weights*}

In rats given $10 \mathrm{ppm}$ TETH, increases were seen in the brain weight of both sexes and in the adrenal weight of males. The thymus and spleen of both sexes of rats on 5 and $10 \mathrm{ppm}$, the ovaries, uterus and prostate of rats on $10 \mathrm{ppm}$ and the liver, thyroid and pituitary gland of male rats on $10 \mathrm{ppm}$ suffered a decrease in weight. In female guinea-pigs on 10 and 20 ppm TETH, the weight of the pituitary gland was increased. The brain weights in both sexes of this species on $20 \mathrm{ppm}$ were also increased. At $20 \mathrm{ppm}$, the liver and thymus in females and the testes suffered a decrease in weight.

With TPTA, decreases in weight were observed in the thyroid of both sexes of rats on 25 and $50 \mathrm{ppm}$ and in the females on 5 and $10 \mathrm{ppm}$, in the pituitary gland of both sexes on 50 $\mathrm{ppm}$, and in the uterus at 25 and $50 \mathrm{ppm}$ and ovaries at $50 \mathrm{ppm}$. In female guinea-pigs there were increased weights of pituitary gland at 10 and $20 \mathrm{ppm}$ and of the kidneys at $20 \mathrm{ppm}$. The liver of males on $20 \mathrm{ppm}$ and of the brain in both sexes on 5,10 and $20 \mathrm{ppm}$ also showed weight increases. The uterus and testes on $20 \mathrm{ppm}$ suffered decreases in weight.

With TPTH, the adrenal weight in both sexes of rats on 25 and $50 \mathrm{ppm}$ was increased compared with the weight of the pituitary gland in females on 25 and 50 ppm and that of the ovaries in rats on $50 \mathrm{ppm}$ which was decreased. The thyroid in both sexes of rats on 25 and $50 \mathrm{ppm}$, the pancreas and uterus in females on $50 \mathrm{ppm}$ and the prostate in this group suffered decreases in weight. In guinea-pigs, there were weight decreases in the spleen of females on 10 and $20 \mathrm{ppm}$ and in the thymus of both sexes and uterus and testes at 20 ppm.

\section{Water content of brain and spinal cord}

The results of the two methods which were used to determine the water content in brain and spinal cord differed. The results obtained with the iodometric titration method are about $3.5 \%$ lower than the results given with the method involving drying to constant weight.

Table 3 records the average water content of brain and spinal cord of the different groups. Guinea-pigs of both sexes on $50 \mathrm{ppm}$ TPTA or TPTH and rats on $20 \mathrm{ppm}$ and female rats on $10 \mathrm{ppm}$ TETH died in the course of the experiment. In these animals the water content of brain and spinal cord was also estimated, but since the animals died at different times, no statistical calculations could be made. But from the values seen in Table 3 it seems that in these animals also an increase in water content is present. However this increase may be explained perhaps by postmortem changes. A significant increase of the water content in brain and spinal cord occurred in the following groups: rats on 5 and 10 ppm; guinea-pigs on 10 and $20 \mathrm{ppm}$ TETH; female rats on $50 \mathrm{ppm}$ (only spinal cord) and guinea-pigs $20 \mathrm{ppm}$ TPTA. A significant increase was found in the spinal cord of female rats given $50 \mathrm{ppm}$ TPTH or TPTA.

From the results it is evident that in untreated animals the water content in the brain is higher than in the spinal cord. The increase of the water content in the brain runs parallel with the increase of water content in the spinal cord (Table 3).

Table 3 also shows that rats are more sensitive to TETH than guinea-pigs and this species is possibly more sensitive to TPTA and TPTH. There is some indication that guinea-pigs and rats are more susceptible to TPTA than to TPTH. Both species did not show any sex difference in sensitivity to the three organotin compounds.

-Relative to body weight in the absence of growth retardation and relative to heart weight in the presence of growth retardation. 
Table 3. Water content $(\%)$ of brain and spinal cord of rats and guinea-pigs receiving TETH, TPTA or TPTH at dietary levels of 0-50 ppm for 12 wk

\begin{tabular}{|c|c|c|c|c|c|c|c|c|c|c|c|c|}
\hline \multirow{3}{*}{$\begin{array}{c}\text { Dietary } \\
\text { level } \\
\text { (ppm) }\end{array}$} & \multicolumn{4}{|c|}{ TETH } & \multicolumn{4}{|c|}{ TPTA } & \multicolumn{4}{|c|}{ ТРТН } \\
\hline & \multicolumn{2}{|c|}{ Rat } & \multicolumn{2}{|c|}{ Guinea-pig } & \multicolumn{2}{|c|}{ Rat } & \multicolumn{2}{|c|}{ Guinea-pig* } & \multicolumn{2}{|c|}{ Rat } & \multicolumn{2}{|c|}{ Guinea-pig } \\
\hline & $\mathbf{M}$ & $\mathbf{F}$ & $\mathbf{M}$ & $\mathbf{F}$ & $\mathbf{M}$ & $\mathrm{F}$ & $\mathbf{M}$ & $\mathrm{F}$ & $\mathbf{M}$ & $\mathbf{F}$ & $\mathbf{M}$ & $\mathbf{F}$ \\
\hline \multicolumn{13}{|c|}{ Brain } \\
\hline $\begin{array}{l}0 \\
2 \cdot 5\end{array}$ & $79 \cdot 0$ & $78 \cdot 1$ & $80 \cdot 5$ & $80 \cdot 5$ & $77 \cdot 2$ & $77 \cdot 4$ & $77 \cdot 7$ & $76 \cdot 8$ & $78 \cdot 2$ & $78 \cdot 0$ & $\begin{array}{l}80 \cdot 2 \\
80 \cdot 2\end{array}$ & $\begin{array}{l}80 \cdot 3 \\
80 \cdot 0\end{array}$ \\
\hline 5 & $80 \cdot 2 \dagger$ & $80.8 \dagger$ & $80 \cdot 6$ & $81 \cdot 2$ & $77 \cdot 2$ & $77 \cdot 1$ & $77 \cdot 6$ & $78 \cdot 1$ & $78 \cdot 2$ & $77 \cdot 9$ & $80 \cdot 3$ & $80 \cdot 4$ \\
\hline 10 & $81.2 t$ & $81 \cdot 2 t$ & $81.5 \dagger$ & $81 \cdot 2 \xi$ & $77 \cdot 0$ & $77 \cdot 4$ & $77 \cdot 8$ & $78 \cdot 4$ & $78 \cdot 3$ & $77 \cdot 9$ & $80 \cdot 2$ & $80 \cdot 2$ \\
\hline 20 & $83 \cdot 7 \ddagger$ & $84 \cdot 7 t$ & $82 \cdot 7 \|$ & $83.0+$ & & & $80 \cdot 5 \S$ & $79 \cdot 8 \|$ & & & $80 \cdot 4$ & $80 \cdot \overline{7}$ \\
\hline 25 & & & & & $77 \cdot 2$ & $77 \cdot 2$ & & & $78 \cdot 3$ & $78 \cdot 2$ & & \\
\hline 50 & & & & & $77 \cdot 5$ & $77 \cdot 4$ & $82 \cdot 6 t$ & $82 \cdot 1 t$ & $77 \cdot 1$ & $77 \cdot 1$ & $81 \cdot 1 f$ & $81 \cdot 17$ \\
\hline \multicolumn{13}{|c|}{ Spinal cord } \\
\hline $\begin{array}{l}0 \\
2.5\end{array}$ & $69 \cdot 5$ & $69 \cdot 6$ & $70 \cdot 6$ & $70 \cdot 6$ & $68 \cdot 5$ & $68 \cdot 0$ & $66 \cdot 7$ & $67 \cdot 1$ & $69 \cdot 1$ & 69.5 & $\begin{array}{l}70 \cdot 6 \\
70 \cdot 1\end{array}$ & $\begin{array}{l}70 \cdot 8 \\
70 \cdot 5\end{array}$ \\
\hline 5 & $72 \cdot 1 \dagger$ & $73.9+$ & $71 \cdot 2$ & $71 \cdot 2$ & $68 \cdot 7$ & 68.9 & $67 \cdot 4$ & $67 \cdot 0$ & $69 \cdot 3$ & $69 \cdot 0$ & $70 \cdot 3$ & $70 \cdot 3$ \\
\hline 10 & $78.0+$ & $79 \cdot 4 t$ & $72 \cdot 8 \dagger$ & $72 \cdot 6 t$ & 67.9 & $68 \cdot 4$ & $68 \cdot 2$ & 68.0 & $69 \cdot 5$ & 69.8 & $70 \cdot 9$ & $70 \cdot 6$ \\
\hline 20 & $83.2 f$ & $85.0 t$ & $78 \cdot 3+$ & $75.6 \dagger$ & & & $70 \cdot 6 \|$ & $71 \cdot 2 \|$ & & & $71 \cdot 1$ & $70 \cdot 8$ \\
\hline 25 & & & & & $69 \cdot 0$ & $68 \cdot 7$ & & & $70 \cdot 0$ & $69 \cdot 5$ & & \\
\hline 50 & & & & & $69 \cdot 8$ & $69.9 \S$ & $74.6 t$ & $74 \cdot 2 \ddagger$ & $69 \cdot 9$ & $69 \cdot 6 \S$ & $73 \cdot 47$ & $73 \cdot 7 \ddagger$ \\
\hline
\end{tabular}

$M=$ Male $\quad F=$ Female

-In this group, water content was estimated by iodometric titration method compared with all other groups in which the method of drying to constant weight was employed.

†Significantly different from controls: $P \leqslant 0.001$.

$\ddagger$ Animals died at different times and no statistical calculation was possible.

$\S$ Significantly different from controls: $0.05 \geqslant P>0.01$.

||Significantly different from controls: $0.01 \geqslant P>0.001$

\section{Mortality}

Table 4 summarizes the mortality data. It appears that rats are more sensitive to TETH than guinea-pigs but the reverse situation holds for TPTA and TPTH. In general the animals given the higher dose levels (rats on $20 \mathrm{ppm}$ TETH; guinea-pigs on $50 \mathrm{ppm}$ TPTA and TPTH) died in the first half of the experiment, while the animals on the lower dose levels (rats on $10 \mathrm{ppm}$ TETH, guinea-pigs on $20 \mathrm{ppm}$ TPTA) died later. No sex difference in mortality was found.

Table 4. Mortality of rats and guinea-pigs receiving TETH, TPTA or TPTH at dietary levels of 0-50 ppm for $12 \mathrm{wk}$

\begin{tabular}{|c|c|c|c|c|c|c|c|c|}
\hline \multirow[b]{2}{*}{ Substance } & \multirow[b]{2}{*}{ Species } & \multicolumn{6}{|c|}{ No. of animals dying in each group } & \multirow[b]{2}{*}{50} \\
\hline & & $\mathbf{0}$ & $2 \cdot 5$ & 5 & 10 & 20 & 25 & \\
\hline \multirow[t]{2}{*}{ TETH } & Rat & $0 / 20$ & & $0 / 20$ & $7 / 20$ & $20 / 20$ & & \\
\hline & Guinea-pig & $1 / 20$ & & $1 / 20$ & $1 / 20$ & $1 / 20$ & & \\
\hline \multirow[t]{2}{*}{ TPTA } & Rat & $2 / 44$ & & $0 / 20$ & $0 / 20$ & & $0 / 20$ & $1 / 20$ \\
\hline & Guinea-pig & $0 / 44$ & & $1 / 20$ & $1 / 20$ & $5 / 20$ & & $20 / 20$ \\
\hline \multirow[t]{2}{*}{ TPTH } & Rat & $0 / 20$ & & $0 / 20$ & $0 / 20$ & & $0 / 20$ & $1 / 20$ \\
\hline & Guinea-pig & $0 / 40$ & $0 / 20$ & $0 / 20$ & $1 / 20$ & $1 / 20$ & & $20 / 20$ \\
\hline
\end{tabular}




\section{Pathology}

In rats and guinea-pigs a number of pathological changes was found which was not dose related and which is common in our rat and guinea-pig strain; for this reason these are not mentioned. Only those changes which appear to be related to the treatment with the organotin compounds are summarized.

All dose levels of TETH induced interstitial oedema in the brain and spinal cord of rats. This interstitial oedema is characterized by interstitial spaces in the white matter, containing aqueous fluids. A doubtful oedema in spinal cord was found in three animals on $10 \mathrm{ppm}$, two on $25 \mathrm{ppm}$ and one each on $50 \mathrm{ppm}$ TPTA and on $50 \mathrm{ppm}$ TPTH respectively. In the same groups an increase was seen in water content of the brain and spinal cord. In two of the animals on the highest dose level the brain weight was increased.

In spite of the fact that in guinea-pigs on 10 and $20 \mathrm{ppm}$ TETH an increase of water content of the brain and spinal cord was found, only in 5 animals, 2 females and 3 males of the $20 \mathrm{ppm}$ group, interstitial oedema was found. A doubtful oedema in the brain occurred in 4 animals on $20 \mathrm{ppm}$ and two on $50 \mathrm{ppm}$ TPTH, one on $5 \mathrm{ppm}$ and one on $50 \mathrm{ppm}$ TPTA. Guinea-pigs receiving TETH or TPTH exhibited a slightly increased incidence of interstitial pneumonia.

Apart from these findings in guinea-pigs changes in the lymphopoietic system were apparent the severity of which increased with increasing dose level. These changes were absent in the control animals. These changes consisted of an atrophy of the white pulp of the spleen (Figs. 3 and 4). Furthermore mycotic necrotizing inflammation in the mesenteric lymph glands and mycotic enteritis was found. These data are summarized in Table 5 . No sex difference in respect of these changes was found.

Table 5. Histopathological findings in the lymphopoietic system of guinea-pigs receiving TPTA or TPTH at dietary levels of 0-50 ppm for $12 \mathrm{wk}$

\begin{tabular}{|c|c|c|c|c|c|c|c|c|}
\hline \multirow{3}{*}{$\begin{array}{l}\text { Histopathological } \\
\text { findings }\end{array}$} & \multicolumn{8}{|c|}{ No. of animals displaying lesions in group } \\
\hline & \multicolumn{5}{|c|}{ TPTA (ppm) } & \multicolumn{3}{|c|}{ TPTH (ppm) } \\
\hline & 0 & 5 & 10 & 20 & 50 & 0 & 20 & 50 \\
\hline $\begin{array}{l}\text { Atrophic white pulp of spleen } \\
\text { Mycotic necrotizing } \\
\text { inflammation of mesentric }\end{array}$ & - & - & - & 1 & 5 & - & 5 & 15 \\
\hline lymph glands & - & 1 & 1 & 2 & 12 & - & - & 8 \\
\hline Mycotic enteritis & - & - & 1 & - & 5 & - & - & 3 \\
\hline
\end{tabular}

\section{DISCUSSION}

Our experiments confirmed the results of Magee et al. (1957) who showed that TETH induced interstitial oedema in the brain and spinal cord of rats at levels of 10 and $20 \mathrm{ppm}$ for 2-7 wk. In the present experiments, $5 \mathrm{ppm}$ of the TETH in rats and $20 \mathrm{ppm}$ in guineapigs for 12 wk proved sufficient to confirm these findings. Lesions of the central nervous system were not seen in rats given TPTA or TPTH, except a few histologically-doubtful cases of interstitial oedema in the spinal cord. The water content of the brain and spinal cord was not increased significantly except in the spinal cord of female rats on $50 \mathrm{ppm}$ of TPTA or TPTH. The water content of both these organs in guinea-pigs on 20 ppm TPTA was increased. Histologically, only a few animals given TPTH or TPTA displayed interstitial oedema of the brain. 
Klimmer (1964) found that rats fed $50 \mathrm{ppm}$ TPTA for 105 days showed a high mortality $(14 / 20)$ and in the brain of all rats perivascular cavities containing fluid were found. This finding was considered to be an artefact. In the spleen of the animals a reactive white pulpa was seen. In the present rat experiment only one death occurred with $50 \mathrm{ppm}$ TPTA.

From the data on brain weight and water content of the brain and spinal cord, it can be concluded that only TPTA showed a similar effect on the central nervous system as TETH, the only difference being that a higher dose level of the triphenyltin compound was necessary. Guinea-pigs were found to be more sensitive to TPTA and TPTH than rats.

Magee et al. (1957) observed testicular atrophy following prolonged exposure of rats to alkyltin compounds. These findings could not be confirmed in the present rat and guineapig experiments.

Whilst significant and non-significant changes in organ weight were manifest, only weight changes of brain, thymus, thyroid, spleen and testes were dose related in some instances. The brain weights were increased with 25 and $50 \mathrm{ppm}$ of TPTH in rats and with $20 \mathrm{ppm}$ of TPTA in guinea-pigs. With TETH these effects were produced at and above $10 \mathrm{ppm}$.

The most striking finding emerging from the haematological studies was the decrease in the number of leucocytes and lymphocytes (lymphopenia). In rats these changes were found at all dose levels of TPTH and in guinea-pigs at all dose levels of TPTA and TPTH but were absent in both species given TETH. In the group with 10 ppm TPTA only a significant decrease in leucocytes was found.

The decrease in lymphocytes accompanied in a number of animals by an atrophy of the lymphopoietic tissue induced by the TPTA and TPTH (Fig. 4) caused possibly a lowering of general resistance to disease. The decrease in thymus and spleen weight, supports this hypothesis. In the circumstances of reduced resistance, a mycotic infection (Absidia corynbifora) could develop in the animals, resulting in early deaths of a great number of animals on the $50 \mathrm{ppm}$ dose levels of TPTA and TPTH. In rats there was only a tendency to atrophy of the white pulp of the spleen. The thymus and spleen weights were normal. In guinea-pigs on 10 and $20 \mathrm{ppm}$ of TETH a tendency (not significant) to lymphopenia was manifest.

Because of the findings in alkyltin toxicity studies it was assumed that changes in the central nervous system might serve as a criterion for assessing the toxicity of triphenyltin compounds. The present experiments indicate that the effect on lymphopoiesis is a more sensitive criterion.

This aspect will be carefully examined in the 2-yr studies now in progress in rats and dogs, elsewhere in the Netherlands.

Acknowledgements-The toxicity studies were carried out on request of Philips-Duphar N.V., Amsterdam. Prof. Dr. G. J. M. van der Kerk of the Organic Chemical Institute T.N.O., Utrecht, kindly provided the sample of TETH for which we are very thankful. The determinations of the water content with the "drying to constant weight" method were carried out by Dr. M. E. Stas of the Department for Chemical Analysis of Food of the Institute to whom our thanks are due. We are very grateful to Miss J. L. van Zwet of the Institute's Hematology Department, Regional Laboratory, District Utrecht for her technical assistance in the haematological studies.

\section{REFERENCES}

Eberius, E. (1958). Wasserbestimmung mit Karl-Fischer-Lösung. Monographie N 65. Angewandte Chemie. Verlag Chemie, Weinheim.

Klimmer, O. R. (1964). Toxikologische Untersuchungen mit Triphenylzinnacetat. Zentbl. VetMed. 11, 29. Lillie, R. D. (1954). Histopathologic Technic and Practical Histochemistry. p. 329. Blakiston Co., New York.

Magee, P. N., Stoner, H. B. \& Barnes, J. M. (1957). The experimental production of oedema in the central nervous system of the rat by triethyltin compounds. J. Path. Bact. 73, 107.

Wilcoxon, F. (1945). Individual comparisons by ranking methods. Biometr. Bull. 1, 80. 


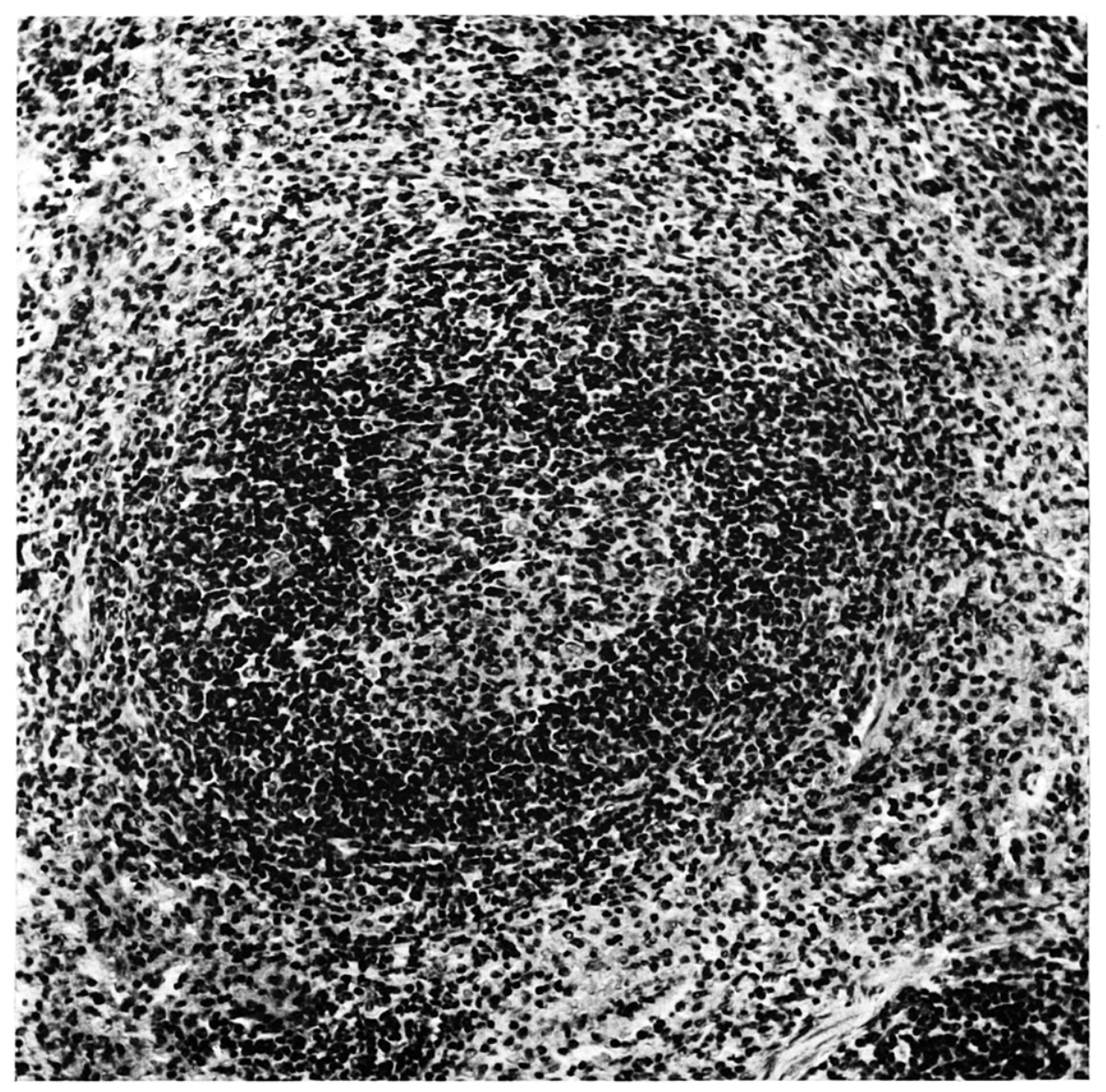

Fig. 3. Photomicrograph of spleen of control guinea-pig showing Malpighian corpuscles with active germinal centres and crowded marginal zone with lymphocytes. Haemalum and eosin $\times 190$. 


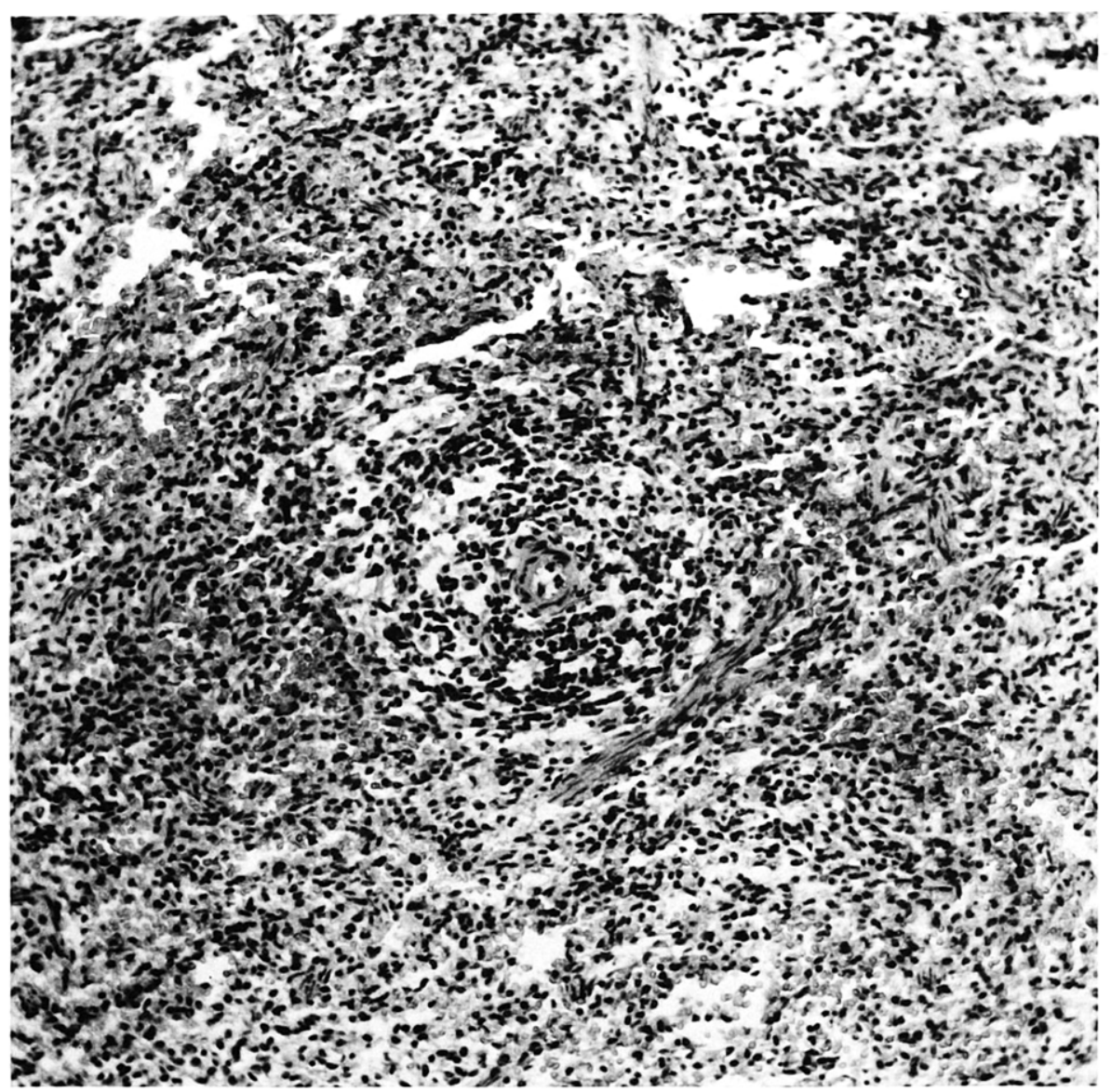

FIG. 4. Photomicrograph of spleen of guinea-pig on $50 \mathrm{ppm}$ TPTH showing atrophy of Malpighian corpuscles with no active centres and only a small number of lymphocytes in the lose reticular tissue of the marginal zone. Haemalum and eosin $\times 190$. 


\section{Etudes de toxicité à court terme des composés du triphényl-étain chez le rat et le cobaye}

Résumé-Des études de toxicité à court terme ont été faites chez des rats et des cobayes recevant durant 90 jours, une alimentation contenant de 0 à 50 parts par million (ppm) d'acétate de triphényl-étain (ATPE), d'hydroxyde de triphényl-étain (HTPE) ou d'hydroxyde de triéthylétain(HTEE).

Les doses alimentaires les plus basses qui retardent la croissance chez le rat et le cobaye sont respectivement les suivantes: 5 et 10 ppm pour le HTEE; 25 et 5 ppm pour le ATPE; 50 et $20 \mathrm{ppm}$ pour le HTPE. On a constaté une mortalité accrue dans les groupes suivants: les rats recevant 10 ppm de HTEE ou plus; les cobayes recevant 20 et 50 ppm de ATPE et 50 ppm de HTPE. Chez les rats et les cobayes ayant reçu du HTEE, il s'est produit une paralysie et une pronation des pattes arrières. Ces effets toxiques n'ont pas été mis en évidence chez les animaux traités par le ATPE et le HTPE. Cette observation correspond aux constatations que seuls les animaux traités pas le HTEE présentent un oédème interstitiel du système nerveux central. La teneur en eau du cerveau et de la moelle épinière a augmentée chez les rats et les cobayes recevant respectivement des doses de 5 et $10 \mathrm{ppm}$ de HTEE et chez les cobayes recevant $20 \mathrm{ppm}$ de ATPE. Chez les rates recevant de $50 \mathrm{ppm}$ de ATPE ou de HTPE, seule a augmenté la teneur en eau de la moelle épinière.

Le changement de poids des organes qui pourrait être attribué aux composés organiques de l'étain se limite à une augmentation du poids du cerveau chez les rats et les cobayes recevant du HTEE, et chez les cobayes ayant reçu 5 ppm ou plus de ATPE; et à une diminution du poids du thymus et/ou de la rate chez les rats et les cobayes recevant du HTEE. Les cobayes recevant 5 à $20 \mathrm{ppm}$ de ATPE ou 2,5 à 20 ppm de HTPE présentent une lymphopénie accompagnée chez certains d'entre eux de modifications histologiques du système lymphopoiétique, par exemple: atrophie de la pulpe blanche de la rate. Celle ci conduit probablement à une diminution de la résistance générale, qui facilite l'apparition d'une infection mycotique chez ces animaux.

Jusqu'à présent, les lésions du système nerveux central étaient considérées comme le critère le plus sûr pour l'évaluation de la toxicité des composés organo-stanneux; mais le présent travail montre que l'effet sur la lymphopoièse est un indice plus sensible de l'action toxique des composés du triphényl-étain.

\section{Kurzzeitige Toxizitätsuntersuchungen mit Triphenylzinnverbindungen an Ratten und Meerschweinchen}

Zusammenfassung-Kurzzeitige Toxizitätsuntersuchungen wurden mit Ratten und Meerschweinchen durchgeführt, die 90 Tage lang Futter mit 0 bis 50 ppm Triphenylzinnacetat (TPZA), Triphenylzinnhydroxyd (TPZH) oder Triäthylzinnhydroxyd (TAZH) erhielten.

Die niedrigsten Konzentrationen im Futter, die bei Ratten bzw. Meerschweinchen das Wachstum verzögerten, waren wie folgt: 5 und $10 \mathrm{ppm} \mathrm{TAZH;} 25$ und $5 \mathrm{ppm}$ TPZA; 50 und $20 \mathrm{ppm}$ TPZH. Eine Erhöhung der Mortalität wurde bei folgenden Gruppen festgestellt: bei Ratten mit 10 ppm oder darüber TAZH, bei Meerschweinchen mit 20 und 50 ppm TPZA und 50 ppm TPZH. Bei Ratten und Meerschweinchen, die TAZH erhielten, entwickelten sich Lähmung und Pronation der Hinterbeine. Diese toxischen Zeichen wurden bei den mit TPZA und TPZH behandelten Tiere nicht festgestellt. Diese Beobachtung wurde mit dem Befund in Beziehung gebracht, daß sich nur bei den mit TAZH behandelten Tieren interstitielle Ödeme des Zentralnervensystem nachweisen ließen. Bei Ratten bzw. Meerschweinchen war bei Mindestkonzentrationen von 5 bzw. 10 ppm TAZH und bei Meerschweinchen von 20 ppm TPZA der Wassergehalt des Gehirns und des Rückenmarks erhöht. Bei weiblichen Ratten, die 50 ppm TPZA oder TPZH erhalten hatten, war nur der Wassergehalt des Rückenmarks erhöht.

Die Ånderungen der Organgewichte, die zur Anwendung der Organozinnverbindungen in Beziehung gebracht werden konnten, beschränkten sich auf die Erhöhung des Gehirngewichts der Ratten und Meerschweinchen, an die TAZH verabreicht wurde, und der Meerschweinchen, die 5 ppm oder darüber TPZA erhielten, sowie auf eine Verminderung des Thymus- und bzw. oder Milzgewichts bei Ratten und Meerschweinchen, die TAZH erhielten. Meerschweinchen, die 5-20 ppm TPZA oder 2,5-20 ppm TPZH erhielten, zeigten Lymphopenie, die bei einer Anzahl von Tieren von histologischen Veränderungen im lymphopoetischen System, nämlich einer Atrophie der weißen Pulpa der Milz, begleitet wurden. Dies führte vermutlich zu einer Herabsetzung der allgemeinen Widerstandsfähigkeit, so daß sich bei den Tieren eine mykotische Infektion entwickelte.

Bisher galten Schäden am Zentralnervensystem als das empfindlichste Kriterium zur Beurteilung der Toxizität von Organozinnverbindungen. Die vorliegende Arbeit zeigt, daß der Einfluß auf die Lymphopoese ein noch empfindlicheres Anzeichen für die toxische Wirkung von Triphenylzinnverbindungen ist. 